\title{
Radiological Effects of Soil and Rock Samples of Different Libyan Regions
}

\author{
Abdu Assalam A. Algattawi ${ }^{*}$, Mohammed Fayez-Hassan², Emad Ibrahim Khalil ${ }^{3}$, Hilmy Abo Elez ${ }^{3}$ \\ ${ }^{1}$ Faculty of Technical Electronic, Tripoli, Libya \\ ${ }^{2}$ Experimental Nuclear Physics Department, NRC, EAEA, Cairo, Egypt \\ ${ }^{3}$ Department of Physics, Zagazig University, Zagazig, Egypt \\ Email: *aagattawi@gmail.com
}

How to cite this paper: Algattawi, A.A.A., Fayez-Hassan, M., Khalil, E.I. and Elez, H.A. (2019) Radiological Effects of Soil and Rock Samples of Different Libyan Regions. Engineering, 11, 247-259.

https://doi.org/10.4236/eng.2019.115018

Received: March 17, 2019

Accepted: May 5, 2019

Published: May 8, 2019

Copyright (c) 2019 by author(s) and Scientific Research Publishing Inc. This work is licensed under the Creative Commons Attribution International License (CC BY 4.0). http://creativecommons.org/licenses/by/4.0/

\begin{abstract}
The activity concentration of natural radioactivity for soil samples collected from western and mid Libyan regions were measured using HPGe detector. The average activity concentration of ${ }^{226} \mathrm{Ra},{ }^{232} \mathrm{Th}$ and ${ }^{40} \mathrm{~K}$ for ten regions was found to be $51.86 \pm 7.14,75.56 \pm 10.95$ and $128.98 \pm 6.88 \mathrm{~Bq} / \mathrm{kg}$ respectively. The results obtained for the corresponding nuclides ${ }^{226} \mathrm{Ra}$ and ${ }^{232} \mathrm{Th}$ are above the worldwide average values ( 35 and $30 \mathrm{~Bq} / \mathrm{kg}$ ) while ${ }^{40} \mathrm{~K}$ was smaller than worldwide average $(400 \mathrm{~Bq} / \mathrm{kg})$. The average outdoor absorbed dose and the annual effective dose rates due to ${ }^{226} \mathrm{Ra},{ }^{232} \mathrm{Th}$ and ${ }^{40} \mathrm{~K}$ were observed to be $21.51 \pm 2.93 \mathrm{nGy} / \mathrm{h}$ and $0.297 \pm .03 \mathrm{mSv} / \mathrm{y}$ respectively, which are lower than world average values $(60 \mathrm{nGy} / \mathrm{h}$ and $0.8 \mathrm{mSv} / \mathrm{y})$. The radium equivalent activity and external hazard indices were found less than the world wide average values.
\end{abstract}

\section{Keywords}

Activity Concentration, Absorbed Dose, Effective Dose, Activity Values, Soil Samples, Western and Mid Libya

\section{Introduction}

The knowledge of radionuclides distribution and radiation levels in the environment is important for assessing the effects of radiation exposure due to both terrestrial and extraterrestrial sources. Natural background radiation is of terrestrial and extraterrestrial origin. Terrestrial radiation is due to radioactive nuclides present in varying amounts in rocks, building materials, water, soils and atmosphere. Natural radionuclides of uranium ${ }^{238} \mathrm{U}$, thorium ${ }^{232} \mathrm{Th}$ and potassium ${ }^{40} \mathrm{~K}$ are present in the earth's crust. When these radionuclides and their 
daughters in the series undergo decays gamma rays, beta and alpha radiations are released to the environment. Therefore, human beings are continuously exposed to ionizing radiation both inside and outside their dwellings. People ingest and inhale radionuclides through their food, air and water. The gamma ray exposure in room is due to radiation emitted decay products of ${ }^{226} \mathrm{Ra},{ }^{232} \mathrm{Th}$ series and ${ }^{40} \mathrm{~K}$. Human has always been exposed to natural radiation arising from the earth as well as from outside the earth [1] [2] [3]. Natural environmental radioactivity and the related external exposure due to gamma radiation depend mainly on the geological and geographical conditions, and appear at different levels in the soils of each region in the world. Every building construction material contains different quantities of natural radioactive nuclides. Radiation exposure due to building materials can be divided into external and internal exposure. The external exposure is caused by direct gamma radiation whereas internal exposure is caused by the inhalation of radon $\left({ }^{222} \mathrm{Rn}\right)$, thorn $\left({ }^{220} \mathrm{Rn}\right)$ and their short lived decay products. As, radon is a noble gas, it can transport easily through porous media for instance building materials, while usually only a fraction of that produced in the material reaches the surface and enters the indoor air.

The natural radioactivity in the environment is the main source of radiation exposure for human body. Natural radionuclide in soil contributes a significant amount of background radiation exposure to the population through inhalation and ingestion. It can be also transferred to plants and foods and drinking water.

According to A.L.A.R.A, principle, the radium equivalent $\mathrm{Ra}_{\mathrm{eq}}$, the external hazard index $\mathrm{H}_{\mathrm{ex}}$ the absorbed Dose Rate A.D.R and the Annual Effective Dose Equivalent. E.D.E were estimated and compared with results of other studies and with the worldwide average value. This work was undertaken to measure the activity concentrations and $\gamma$-ray absorbed doses of the naturally occurring radionuclides in soil samples. Another aim of this work is to create the public awareness about the radiation hazards and it will also be helpful to establish a research base line in the investigated regions. Some previous studies of Libyan soil, Arab and neighbors' countries soil are summarized and tabulated in Table 1.

The two hundred samples (twenty samples for each region) were collected, at depth $1-10 \mathrm{~cm}$. Samples were treated thermally at $60^{\circ} \mathrm{C}$ for 24 hours after that they were sieved to obtain uniform particle size about $550 \mu \mathrm{m}$ then the soil will filled in beaker which was sealed and then average weighted and stored for a month to reach the secular equilibrium.

\section{Materials and Methods}

\section{Sample Collection and Preparation}

The samples are selected from different geographic and geological regions in western and mid Libya. Twenty samples were collected, with average masses varied $0.24-0.53 \mathrm{~kg}$, for each region with separate distance $1 \mathrm{~km}$. The samples information is illustrated in Table 2. 
Table 1. Represents the mean and range activity concentrations of radionuclides for different countries.

\begin{tabular}{ccccc}
\hline \multirow{2}{*}{ Item } & \multicolumn{3}{c}{ Mean activity concentration Bq/kg (range) } & Country \\
\cline { 2 - 5 } & ${ }^{226} \mathrm{Ra}$ & ${ }^{40} \mathrm{~K}$ & Libya, Beach sand of Tripoli, 2008 [4] \\
\hline 1 & $7.5(4-13.5)$ & $4.2(2.8-6.7)$ & $27.5(19-39.6)$ & Libya, Aljabel. Al. Gharbi-Using Portable \\
2 & $(58.8-102.1)$ & - & - & Nuclear Radiation Detector; 2011 [5] \\
3 & - & - & - & Libya, North western,2001 [6] \\
4 & $26.02(17.09-34.03)$ & $30(11-64)$ & $400(140-850)$ & Iraq, kurkukoil field 2006 [7] \\
5 & $20.05(10.87-30.94)$ & $16.43(6.78-20.61)$ & $216.69(127.74-272.7)$ & Qatar state soil in Dukhan oil field 2015 [8] \\
6 & $22.03(1.8-76.4)$ & $27.91(6.3-85.5)$ & $285.0(84-516.7)$ & Jordan, soil in Tafilla, 2012 [9] \\
7 & $16(46-115)$ & 10 & 370 & Kuwait before and After war 2985 [10] \\
8 & $(32.2-63.7)$ & $(44.3-95.6)$ & $(96-102)$ & Egypt, Beach sand Dune 1997 [11] \\
9 & $(5-13.8)$ & $(2.3-15.3)$ & $(29-582)$ & Algeria, 2008 [12] \\
10 & $30(2-110)$ & $25(2-140)$ & $370(66-1150)$ & Syria, phosphate rocks 1981 [13] \\
11 & $23(10-64)$ & $20(10-32)$ & $270(78-780)$ & Nigeria, Akuk, Ondo state 2001 [14]
\end{tabular}

Table 2. Samples information.

\begin{tabular}{cccccc}
\hline Samples. D & Region & $\begin{array}{c}\text { Average } \\
\text { Weight } \\
(\mathrm{gm})\end{array}$ & Type of sample & \multicolumn{2}{c}{ Sample Location } \\
\cline { 5 - 5 } SA1 & Qarabulli & 330 & Coast & $32^{\circ} 44^{\prime}$ & $1^{\circ} 14^{\prime}$ \\
SA2 & Bu-njim & 350 & Sand (desert) & $30^{\circ} 35^{\prime}$ & $15^{\circ} 24^{\prime}$ \\
SA3 & Zawia & 480 & Mountain (stones) & $32^{\circ} 45^{\prime}$ & $12^{\circ} 44^{\prime}$ \\
SA4 & Qaddahea & 510 & Near the coast & $31^{\circ} 22^{\prime}$ & $15^{\circ} 14^{\prime}$ \\
SA5 & Orban & 450 & Sand (Oises) & Near Ghrian & Near Ghrian $^{\prime}$ \\
SA6 & Tajoura & 300 & Sand (desert) & $32^{\circ} 53^{\prime}$ & $13^{\circ} 23^{\prime}$ \\
SA7 & Sokna & 530 & Coast (near sea) & $29^{\circ} 10^{\prime}$ & $16^{\circ} 10^{\prime}$ \\
SA8 & Ghrian & 315 & Coast & $32^{\circ} 21^{\prime}$ & $15^{\circ} 8^{\prime}$ \\
SA9 & Misurata & 450 & Mountain (stones) & $32^{\circ} 25^{\prime}$ & $15^{\circ} 05^{\prime}$ \\
SA10 & Qaser Akhiar & 240 & Desert & Near Qarabulli & Near Qarabulli $^{\prime}$
\end{tabular}

\section{Gamma-Ray Spectrometry}

Gamma spectrometry offers a convenient, direct, and non-destructive method to measure the activity of different radionuclides in the environmental samples. It also offers high efficiency $\mathrm{Nal}(\mathrm{Tl})$ detectors and high resolution (semiconductor detectors) detection. This technique enables the use of large quantities of samples to be counted. It is also possible, in this method, to reduce the essential background to very low values using suitable shielding arrangement.

These advantages together with appropriate ability software (Genie 2000) that have now become available has made the gamma spectrometry method one of 
the most accurate technique for determining the activity concentration of the environmental samples. In the present work, HPGe gamma spectrometer was used for the determination of gamma active radionuclide in soil and rock samples. It is widely used for gamma ray spectroscopy to determine quantitatively the activities of natural ${ }^{40} \mathrm{~K},{ }^{232} \mathrm{Th},{ }^{226} \mathrm{Ra}$ in the environmental samples. The HPGe detectors have very high resolution and $70 \%$ relative efficiency. The spectrum was analyzed using multichannel analyzer (MCA) connected to computer using Genie-2000 software [15]. The sealed sample was placed in the protection unit of gamma ray spectrometry for the counting time of six hours, the energy resolution (FWHM) of this detector is $2.01 \mathrm{keV}$ at $1.33 \mathrm{MeV}\left({ }^{60} \mathrm{CO}\right)$.

\section{Calibration of Gamma-ray Spectrometer System}

The calibration of the spectrometer system for energy measurements is necessary to know the approximate energies of the radiation source being analyzed. The aim of calibration is to identify the radionuclide and activity concentrations present in an environmental sample. Energy calibration is carried out to confirm linear relationship between energy and the number of channels corresponding to that energy, and to determine the energy of each channel in a spectrum. The spectrum is obtained for a reasonable time so that the photo peaks have sufficient counts for analysis. The regions of interest and centroid peak channel numbers are identified.

In the present work, the detector efficiency calibration was performed using standard assurance reference materials and standard soil. These standard reference materials were taken in containers similar to the containers used for filling the soil samples for gamma spectrometric determination. The standard materials and samples were taken in containers of the same size and type so that the geometry remained the same. The samples were counted long enough (one week) to reduce the counting error.

\section{Calculation of Activity Concentrations}

The radioactivity of each sample was measured with keeping the samples one by one on the top of the detector and counted for a period of one day. The activity concentration $(A)$ of each radionuclide in the sample was determined by using the count rates $\left(N_{c}\right)$ (after subtracting the back ground).

$$
A=\frac{N_{c}}{\varepsilon I_{\gamma} W}
$$

where $\varepsilon=$ Efficiency of the detector for the specific energy, $I_{\gamma}=$ Intensity of the gamma ray and $W=$ Sample weight $(\mathrm{kg})$. For the analysis of peak areas of gamma spectra, a computer software programming (Genie 2000) was used [16]. Determination of NORM were carried out by measuring different daughters that emit clear gamma peaks of high intensity to confirm the attainment of radioactive secular equilibrium within the samples between ${ }^{226} \mathrm{Ra}$ and its daughters. This was carried out by measuring ${ }^{226} \mathrm{Ra}$ directly through the $186.2 \mathrm{keV}$ and indirectly by measuring the ${ }^{214} \mathrm{Bi}(609.3,1120.2$ and $1764.5 \mathrm{keV})$ and ${ }^{214} \mathrm{~Pb}(351.9 \mathrm{keV})$ photo peaks. ${ }^{235} \mathrm{U}$ was determined directly through the $143.8 \mathrm{keV}$ photo peak. 
${ }^{232} \mathrm{Th}$ was determined through ${ }^{228} \mathrm{Ac}(911.2 \mathrm{keV}),{ }^{212} \mathrm{~Pb}(238.6 \mathrm{keV}$ after subtract 241.2 value) and ${ }^{208} \mathrm{Tl}(2614 \mathrm{keV})$ photo peaks, and estimation of ${ }^{40} \mathrm{~K}$ through the $1460.8 \mathrm{keV}$ photo peak.

\section{Computation of Radiological Effects \\ Radium equivalent Activity $R_{\text {eq }}$}

The important radionuclides in nature ${ }^{226} \mathrm{Ra},{ }^{232} \mathrm{Th}$ and ${ }^{40} \mathrm{~K}$ are not uniformly distributed,this due to disequilibrium between ${ }^{226} \mathrm{Ra}$ and its decay products.For uniformity in exposure, estimates the radionuclide concentrations have been defined in terms of radium equivalent activity $\left(R a_{e q}\right.$ in $\left.\mathrm{Bq} / \mathrm{kg}\right)$. This allows comparison of the specific activity of materials $\left(A_{\mathrm{Ra}}, A_{\mathrm{Th}}\right.$ and $\left.A_{\mathrm{K}}\right)$ containing different amounts of ${ }^{226} \mathrm{Ra},{ }^{232} \mathrm{Th}$ and ${ }^{40} \mathrm{~K}$ according to:

$$
R a_{e q}=A_{\mathrm{Ra}}+1.43 A_{\mathrm{Th}}+0.077 A_{\mathrm{K}}
$$

\section{External and Internal Hazard Index:}

The hazard index $\left(H_{e x}, H_{i n}\right)$ is the indoor radiation dose rate due to the external/internal exposure gamma radiation construction materials which was calculated by:

$$
\begin{aligned}
& H_{e x}=0.0027 A_{\mathrm{Ra}}+0.0038 A_{\mathrm{Th}}+2.08 \times 10^{-4} A_{\mathrm{K}} \\
& H_{\text {in }}=0.00541 A_{\mathrm{Ra}}+0.0038 A_{\mathrm{Th}}+2.08 \times 10^{-4} A_{\mathrm{K}}
\end{aligned}
$$

\section{Calculation of air absorbed dose rate:}

The external outdoor absorbed gamma dose rates due to terrestrial $\gamma$-rays from the nuclides of ${ }^{226} \mathrm{Ra},{ }^{232} \mathrm{Th}$ and ${ }^{40} \mathrm{~K}$ at $1 \mathrm{~m}$ above the ground level was calculated as :-

$$
\text { A.D.R }=\left(0.461 A_{\mathrm{Ra}}+0.623 A_{\mathrm{Th}}+0.0414 A_{\mathrm{K}}\right) \mathrm{nGyh}^{-1}
$$

About $98 \%$ of the external $\gamma$ dose rate from ${ }^{238} \mathrm{U}$ series is delivered by the ${ }^{226} \mathrm{Ra}$ sub series. So disequilibrium between ${ }^{226} \mathrm{Ra}$ and ${ }^{238} \mathrm{U}$ will not affect the results of dose calculations from the measurement of ${ }^{226} \mathrm{Ra}$. The absorbed dose rate was converted into annual effective dose equivalent by using conversion factor of 0.7 SvGy and 0.2 for the outdoor occupancy factor by considering that the people on the average spent $20 \%$ of the time outdoors.

Effective dose rates:

The Effective dose due to natural activity in soil was calculated by:

$$
\text { (A.E.D.E) in }=8760 \times 0.2 \times 0.7 \times 10^{-3} \text { A.D.R } \mu \mathrm{Svy}^{-1}
$$

\section{Gamma index $\left(I_{\gamma}\right)$ :}

The index $\left(I_{\gamma r}\right)$ is used to estimate the level of $\gamma$-radiation hazard associated with the natural radionuclides in specific investigated samples, is defined as:

$$
I_{\gamma r}=0.007 A_{\mathrm{Ra}}+0.01 A_{\mathrm{Th}}+6.6 \times 10^{4} A_{\mathrm{K}}
$$

For materials that are used in bulk quantities the value of $I_{\gamma} \leq 0.5$ corresponds to a dose rate criterion of $0.3 \mathrm{mSv} \cdot \mathrm{yr}^{-1}$ whereas $0.5 \leq I_{\gamma} \leq 1$ corresponds to a criterion of $1 \mathrm{mSv} \cdot \mathrm{y}^{-1}[17]$

\section{Alpha index $\left(I_{\alpha}\right)$ :}


As radon daughters decay, they emit radioactive $\alpha$-particles and attach to aerosols, dust and other particles in the air. As persons inhale, radon progeny are deposited on the cells lining the airways where the $\alpha$-particles can damage DNA and potentially cause lung cancer. The excess $\alpha$-particles radiation due to radon inhalation originating from building materials is estimated through the $\alpha$-index $\left(I_{\alpha}\right)$, which is defined as follows [14]:

$$
I_{\alpha}=\frac{A_{\mathrm{Ra}}}{200}
$$

The recommended upper limit concentration of ${ }^{226} \mathrm{Ra}$ is $200 \mathrm{~Bq} \cdot \mathrm{kg}^{-1}$ which gives $I_{\alpha}=1$.

\section{Results and Discussion}

In this work the activity concentrations and radiological indices of soil samples, taken from different Libyan sites, are summarized. Activity concentrations for nuclides ${ }^{235} \mathrm{U},{ }^{226} \mathrm{Ra},{ }^{232} \mathrm{Th}$ and ${ }^{40} \mathrm{~K}$ was determined by Equation (1) and the results were tabulated in Table 3 and illustrated together in Figure 1. The highest value is found for sample $\mathrm{S} 10 \mathrm{~A}$, for ${ }^{238} \mathrm{U}\left({ }^{226} \mathrm{Ra}\right) 103.81 \mathrm{~Bq} / \mathrm{kg}$, while SA4 for ${ }^{232} \mathrm{Th}$ $(153.5 \mathrm{~Bq} / \mathrm{kg})$ also SA4 for ${ }^{40} \mathrm{~K}(168.57 \mathrm{~Bq} / \mathrm{kg})$. The highest activity, of the nuclide, may vary from place to place due to chemical changes in elements of soil or using agriculture fertilizers or material wastes, weapons etc. The results for these nuclides are also shown independently through Figure 2.

Table 3. Average activities concentrations of the, ${ }^{226} \mathrm{Ra},{ }^{232} \mathrm{Th}$ and ${ }^{40} \mathrm{~K}$ in $\mathrm{Bq} / \mathrm{kg}$ for the measured samples.

\begin{tabular}{|c|c|c|c|c|}
\hline I. D & ${ }^{226} \mathrm{Ra}$ & ${ }^{232} \mathrm{Th}$ & ${ }^{40} \mathrm{~K}$ & ${ }^{226} \mathrm{Ra} /{ }^{232} \mathrm{Th}$ \\
\hline SA1 & $74 \pm 7.85$ & $63.00 \pm 6.70$ & $146.2 \pm 15.16$ & 1.17 \\
\hline SA2 & $56.83 \pm 6.77$ & $42.96 \pm 4.44$ & $131 \pm 13.39$ & 0.78 \\
\hline SA3 & $33.06 \pm 4.53$ & $40.74 \pm 4.94$ & $146.4 \pm 16.2$ & 2.13 \\
\hline SA4 & $60.16 \pm 6.52$ & $153.5 \pm 16.47$ & $168.57 \pm 17.30$ & 1.56 \\
\hline SA5 & $29.12 \pm 5.42$ & $92.33 \pm 8.79$ & $108.57 \pm 11.14$ & 1.09 \\
\hline SA6 & $30.09 \pm 3.86$ & $102.3 \pm 9.02$ & $116.01 \pm 13.24$ & 0.57 \\
\hline SA7 & $26.71 \pm 5.95$ & $47.62 \pm 6.21$ & $103.44 \pm 10.36$ & 1.42 \\
\hline SA8 & $33.26 \pm 4.49$ & $46.92 \pm 6.36$ & $100.35 \pm 9.65$ & 0.71 \\
\hline SA9 & $71,6 \pm 7.08$ & $47.7 \pm 6.19$ & $140.3 \pm 14.52$ & 2.25 \\
\hline SA10 & $103.81 \pm 11.28$ & $118.3 \pm 11.60$ & N.D & 0.87 \\
\hline Average & $51.86 \pm 5.14$ & $75.56 \pm 7.36$ & $128.98 \pm 12.05$ & 1.305 \\
\hline Max & 103.81 & 153.5 & 168.57 & 2.25 \\
\hline Min & 26.71 & 40.74 & 100.35 & 0.57 \\
\hline S.D & 5.14 & 7.36 & 12.05 & 0.16 \\
\hline
\end{tabular}

N.D., Not Detected. 


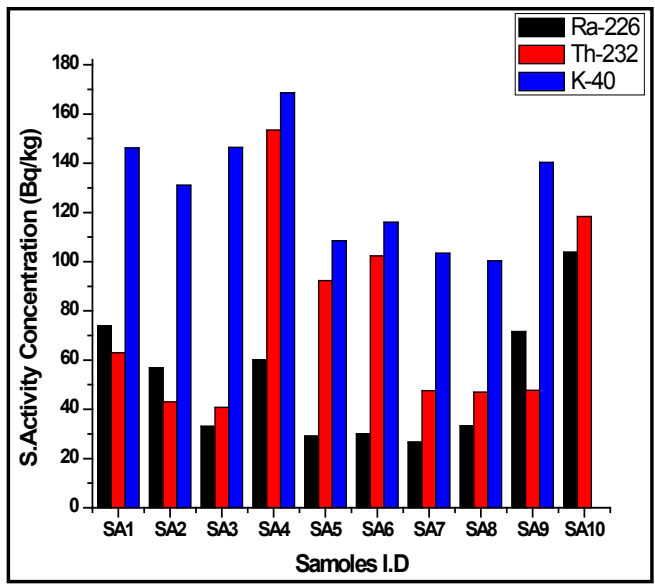

Figure 1. The activity concentration of radionuclides for investigated samples.
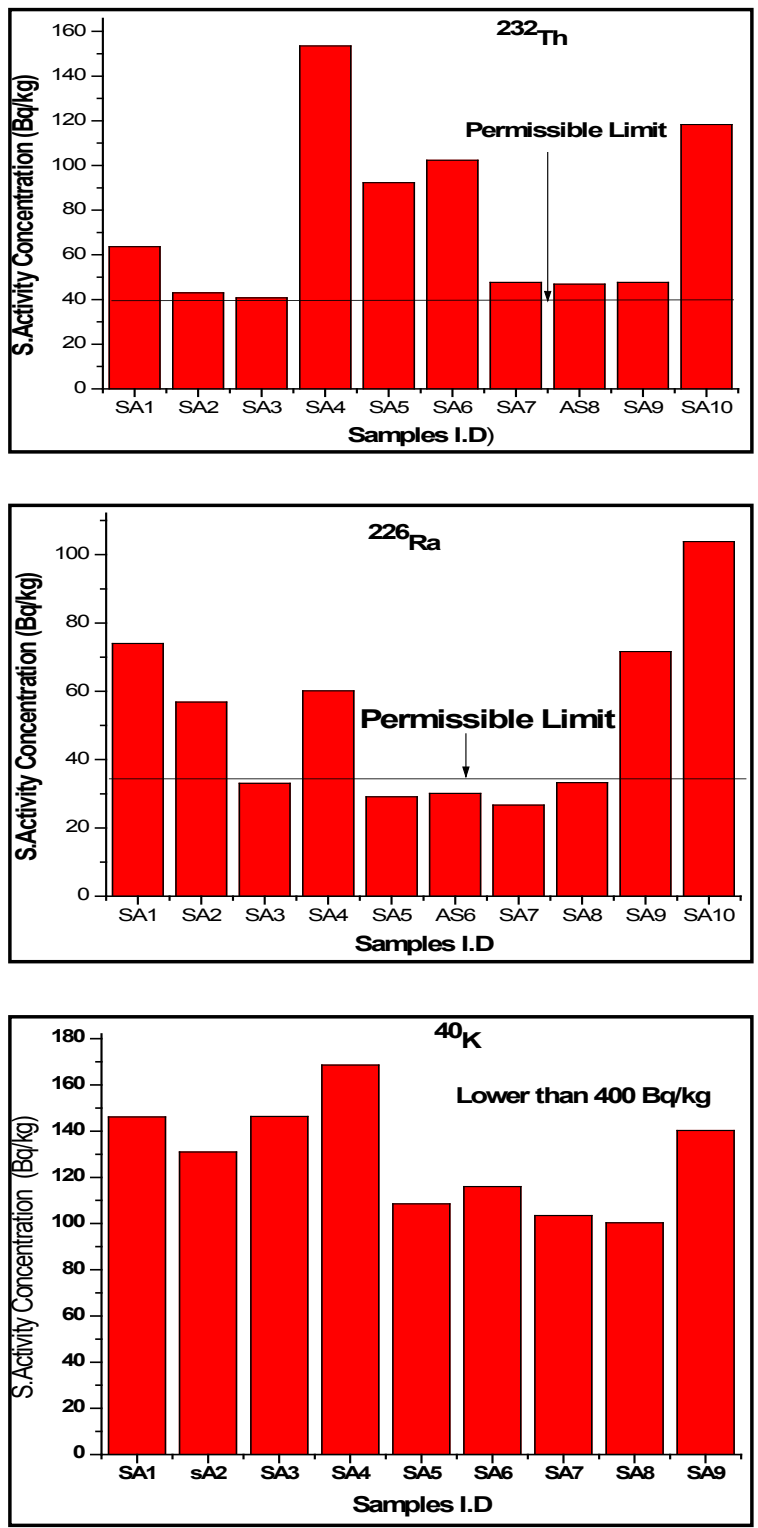

Figure 2. Soil Samples of regions versus average activity concentration of radionuclides. 


\section{${ }^{226}$ Ra activity}

In soil samples the activity concentrations of ${ }^{226} \mathrm{Ra}$ were found in the range of $26 \pm 0.71-103.8 \pm 12.38 \mathrm{~Bq} / \mathrm{kg}$, with an average value $51.68 \pm 7.14 \mathrm{~Bq} / \mathrm{kg}$. This result is higher than the world wide average value of $35 \mathrm{~Bq} / \mathrm{kg}$ for the same radionuclides in soils reported by UNSCEAR.

\section{${ }^{232}$ Th Activity}

The concentration of ${ }^{232} \mathrm{Th}$ is found in the range $40.74 \pm 2.70-153.5 \pm 7.57$ $\mathrm{Bq} / \mathrm{kg}$ with mean $\mathrm{v}$-value $75.56 \pm 10.95 \mathrm{~Bq} / \mathrm{kg}$ this result is higher than the world average of $30 \mathrm{~Bq} / \mathrm{kg}$. SA1 Qarabulli). The ratio concentration of ${ }^{226} \mathrm{Ra}\left({ }^{238} \mathrm{U}\right.$ series) to ${ }^{232} \mathrm{Th}$ is less than unity, (concentration of ${ }^{232} \mathrm{Th}$ is higher than ${ }^{226} \mathrm{Ra}$ ) Figure 3.

\section{${ }^{40} \mathrm{~K}$ Activity}

The activity ${ }^{40} \mathrm{~K}$ is found in the range $(100.35 \pm 4.36)-(168.57 \pm 27.26) \mathrm{Bq} / \mathrm{kg}$ with the average value of $168.98 \pm 6.88 \mathrm{~Bq} / \mathrm{kg}$. This result is mostly lower than the world wide average of $400 \mathrm{~Bq} / \mathrm{kg}$ but SA4 is very high for the same kind of nuclide.

To estimate the health effects, the radiation hazards such as radium equivalent $\left(R a_{e q}\right)$, external and internal hazard index $\left(H_{e x}, H_{i n}\right)$, absorbed dose Rate (A.D.R), effective dose rate (AEDE), level index $\left(I_{\gamma r}\right)$ and $\alpha$-index have been calculated from the activity of nuclides ${ }^{226} \mathrm{Ra},{ }^{232} \mathrm{Th}$ and ${ }^{40} \mathrm{~K}$ using the Equations (2)-(8) respectively and the values have shown in Table 4 and Figure 4.

Table 4, shows that the radium equivalent $\left(\mathrm{Ra}_{\mathrm{eq}}\right)$ is found in the range (102.59 $\pm 20-292.64 \pm 34.33 \mathrm{~Bq} / \mathrm{kg}$ ), and has average value of $157.25 \pm 13.18 \mathrm{~Bq} / \mathrm{kg}$. The average value of radium equivalent is less than the safe limits $370 \mathrm{~Bq} / \mathrm{kg}$ [2]. The

Table 4. Gives average activity concentration compared with others.

\begin{tabular}{cccccccc}
\hline I. D & $\begin{array}{c}\mathrm{Ra}_{\mathrm{eq}} \\
(\mathrm{Bq} / \mathrm{kg})\end{array}$ & $\begin{array}{c}\text { A. D. R } \\
(\mathrm{n} \mathrm{Gy} / \mathrm{y})\end{array}$ & $H_{i n}$ & $H_{e x}$ & $\begin{array}{c}\text { A. E. D. E } \\
(\mu . \mathrm{Ss} / \mathrm{y})\end{array}$ & $\begin{array}{c}I_{\gamma r} \\
(\mathrm{~Bq} / \mathrm{kg})\end{array}$ & Index \\
\hline S.A1 & 175.34 & 34.35 & 0.67 & 0.469 & 421.31 & 1.980 & 0.37 \\
S.A2 & 128.34 & 26.36 & 0.49 & 0.34 & 323.30 & 1.70 & 0.28 \\
S.A3. & 102.59 & 15.39 & 0.36 & 0.274 & 188.81 & 1.69 & 0.17 \\
S.A4 & 292.64 & 28.31 & 0.94 & 0.78 & 347.28 & 2.10 & 0.30 \\
S.A5 & 169.51 & 13.77 & 0.53 & 0.45 & 168.94 & 1.28 & 0.15 \\
S.A6 & 185.31 & 14.26 & 0.57 & 0.49 & 174.89 & 1.37 & 0.16 \\
S.A7 & 102.77 & 12.49 & 0.34 & 0.27 & 153.23 & 1.22 & 0.13 \\
S.A8 & 108.08 & 15.51 & 0.37 & 0.28 & 190.23 & 1.23 & 0.18 \\
S.A9 & 150.61 & 33.18 & 0.59 & 0.40 & 407.03 & 1.90 & 0.36 \\
S.A10 & 272.97 & 48.30 & 1.011 & 0.72 & 592.42 & 0.72 & 0.52 \\
Average & 157.247 & 21.51 & 0.59 & 0.45 & 296.74 & 1.52 & 0.25 \\
Max.- & 292.64 & 34.35 & 1.01 & 0.78 & 263.89 & 2.10 & 0.52 \\
Min. & 102.591 & 12.49 & 0.34 & 0.27 & 153.23 & 0.72 & 0.13 \\
S.D & 16.05 & 2.93 & 0.023 & 0.027 & 30 & 0.43 & 0.096 \\
\hline
\end{tabular}




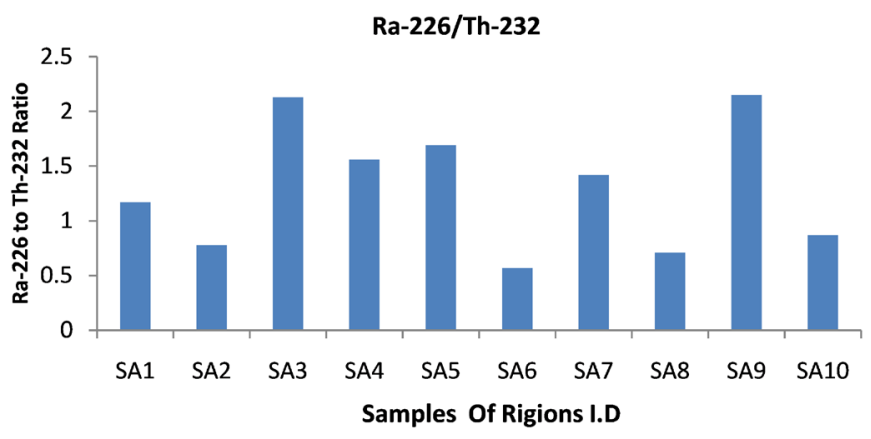

Figure $3 .{ }^{226} \mathrm{Ra}\left({ }^{238} \mathrm{U}\right.$ Series) to ${ }^{232} \mathrm{Th}$ ratio.
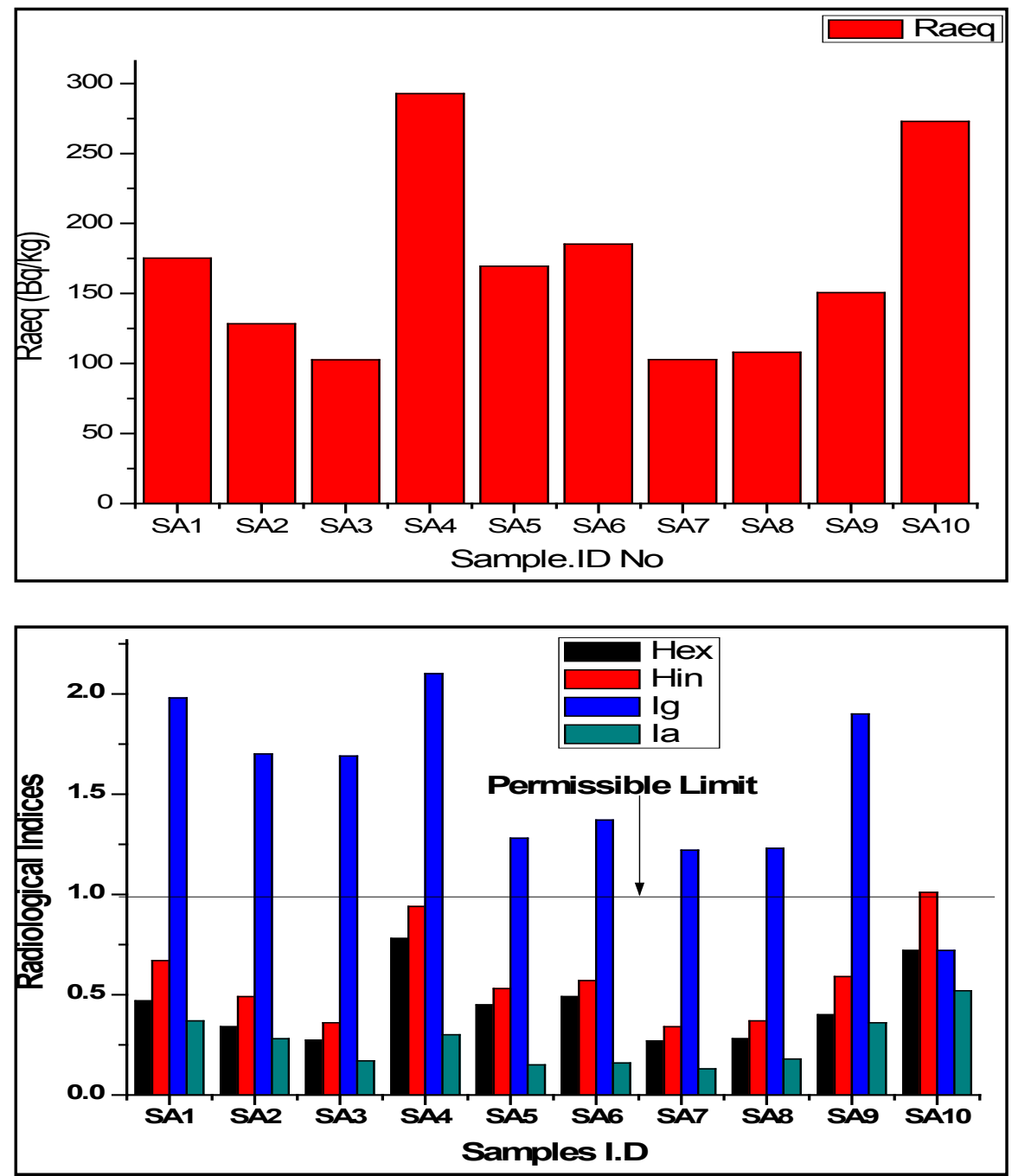

Figure 4. Average radiological indices of the investigated regions.

mean value of external radiation hazard index is $(0.45 \pm 0.09)$ which is less than 1 and confirm it as safe to carry out the activities for the human in that region. The outdoor air absorbed dose rate due terrestrial gamma rays at $1 \mathrm{~m}$ above the ground were calculated for ${ }^{226} \mathrm{Ra},{ }^{232} \mathrm{Th}$ and ${ }^{40} \mathrm{~K}$ and the range is $(12.49 \pm 1.66)$ $(34.35 \pm 3.76) \mathrm{nGy} / \mathrm{h}$ with an average $21.52 \pm 2.20 \mathrm{nGy} / \mathrm{h}$ which is lower than the 
world average of $60 \mathrm{nGy} / \mathrm{h}$ [2]. The annual effective dose rate equivalent is calculated using a conversion factor of $0.7 \mathrm{~Sv} / \mathrm{Gy}$ to convert the absorbed dose rate to the effective dose equivalent and 0.2 for the outdoor occupancy factor. The annual effective dose rates are found in the range of $(153.23 \pm 14.50-263.89 \pm$ 28.1) $\mu \mathrm{Sv} / \mathrm{y}$ with an average-e $296.75 \pm 29.60 \mu \mathrm{Sv} / \mathrm{y}$ which is lower than the world average of $1000 \mu \mathrm{Sv} / \mathrm{y}$ for the general public (UNSCEAR, 2000). The representative level index $I_{\gamma r}$ Equation (6) must be less than unity. For the investigated samples this index is in average $1.52 \pm 0.20 \mathrm{~Bq} / \mathrm{kg}$, where higher than unity in most samples.

\section{Correlation study:}

Correlation analyses were performed to reveal the possible relationship between concentrations of different radionuclides in the samples. The Pearson product-moment correlation matrixes for the correlation coefficient values (R) between the radionuclides average activity concentrations were calculated (Table 5). The correlation between ${ }^{226} \mathrm{Ra} \&{ }^{232} \mathrm{Th},{ }^{226} \mathrm{Ra} \&{ }^{40} \mathrm{~K}$ and Radium and absorbed dose in air of soil samples is computed from the concentrations of these radionuclides respectively. There is a weak correlation between $\left({ }^{226} \mathrm{Ra},{ }^{232} \mathrm{Th}\right)$ and between $\left({ }^{226} \mathrm{Ra},{ }^{40} \mathrm{~K}\right)$ for the samples. The value of correlation between ${ }^{226} \mathrm{Ra}$ and absorbed dose significantly higher with positive correction [correction coefficient $\mathrm{R}=0.99$ ] as shown in Figure 5 .

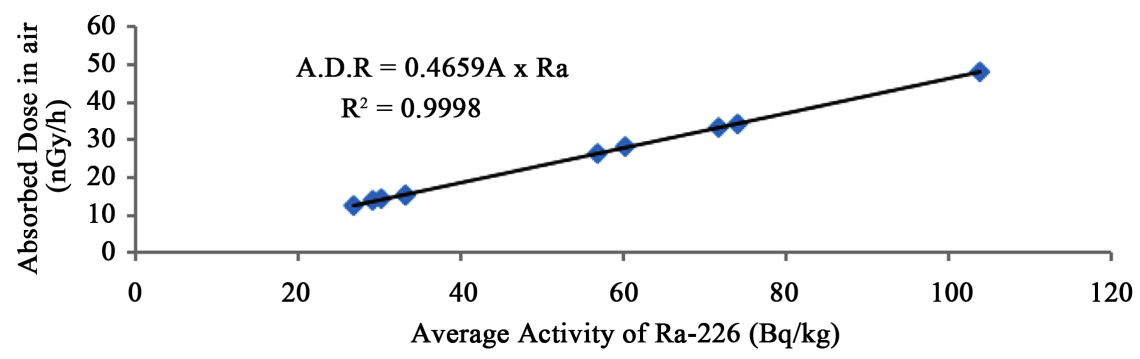

Figure 5. Correlation between ${ }^{226} \mathrm{Ra}$ and absorbed dose.

Table 5. Average activity concentration in this work and others $(\mathrm{Bq} / \mathrm{kg})$.

\begin{tabular}{ccccc}
\hline Country & ${ }^{238} \mathrm{U}$ & ${ }^{232} \mathrm{Th}$ & ${ }^{40} \mathrm{~K}$ & Ref. \\
\hline Malaysia & $39 \pm 0.7$ & $52 \pm 1$ & $61 \pm 15$ & {$[18]$} \\
Egypt & $79 \pm 2$ & $44 \pm 1$ & $586 \pm 18$ & {$[19]$} \\
Libya & $7.5 \pm 2.5$ & $6.7 \pm 1.9$ & $4.5 \pm 1.3$ & {$[20]$} \\
Iran & $74 \pm 4$ & $69 \pm 4$ & $1130 \pm 32$ & {$[21]$} \\
Turkey & $70 \pm 0.8$ & $83 \pm 1$ & $1234 \pm 7$ & {$[22]$} \\
Kenya & $12.63-72.51$ & $11.45-58.12$ & $234.8-1058.52$ & {$[23]$} \\
Nigeria & $74.74 \pm 5.67$ & $199.23 \pm 43.30$ & $1021.27 \pm 7.14$ & {$[24]$} \\
This work & $51.86 \pm 4.38$ & $75.56 \pm 7.36$ & $128.98 \pm 12.09$ & \\
World wide & 33 & 45 & 412 & {$[2]$} \\
\hline
\end{tabular}




\section{Conclusions}

The activity concentration of ${ }^{226} \mathrm{Ra},{ }^{232} \mathrm{Th}$ and ${ }^{40} \mathrm{~K}$ has been measured for some soil and rock samples from different locations of West and Mid Libya by using gamma-ray spectrometry (HPGe) detector. The activity of ${ }^{226} \mathrm{Ra},{ }^{232} \mathrm{Th}$ and ${ }^{40} \mathrm{~K}$ in samples are found to ranges from $26.71 \pm 5.95$ to $103.31 \pm 11.28 \mathrm{~Bq} \cdot \mathrm{kg}^{-1}, 40.74 \pm$ 4.94 to $153.5 \pm 16.47 \mathrm{~Bq} \cdot \mathrm{kg}^{-1}$ and $100.35 \pm 9.65$ to $168.57 \pm 17.30 \mathrm{~Bq} \cdot \mathrm{kg}^{-1}$, respectively while world average concentrations are 35,30 and $400 \mathrm{~Bq} \cdot \mathrm{kg}^{-1}$ for ${ }^{226} \mathrm{Ra}$, ${ }^{232} \mathrm{Th}$ and ${ }^{40} \mathrm{~K}$, respectively (UNSCEAR, 2000). The average and ranges of activity concentration of ${ }^{226} \mathrm{Ra},{ }^{232} \mathrm{Th}$ in soil of these areas are quite higher than the world average reported values (UNSCEAR, 2000) while for ${ }^{40} \mathrm{~K}$ less than world range. The average value of radium equivalent activity is $157.25 \mathrm{~Bq} \cdot \mathrm{kg}^{-1}$ which is below the recommended value of $370 \mathrm{~Bq} \cdot \mathrm{kg}^{-1}$. The values of absorbed dose rates due to ${ }^{226} \mathrm{Ra},{ }^{232} \mathrm{Th}$ and ${ }^{40} \mathrm{~K}$ in soil samples vary from 12.47 to $34.35 \mathrm{nGy} \cdot \mathrm{h}^{-1}$ with an average value of $21.52 \mathrm{nGy} \cdot \mathrm{h}^{-1}$. The calculated values of absorbed dose have been found lower than global average value. The annual effective dose rates in outdoor is found to vary from 0.153 to $0.264 \mathrm{mSv} \cdot \mathrm{y}^{-1}$ with an average value of 0.297 $\mathrm{mSv} \cdot \mathrm{y}^{-1}$. This is below the limit of $1 \mathrm{mSv} \cdot \mathrm{y}^{-1}$ for general population (UNSCEAR, 2000). The calculated values of external hazard Hex are vary from 0.27 to 0.78 with an average value of 0.45 whereas internal hazard index Hin are vary from 0.34 to 1.01 with an average value of 0.59 . All values of Hex and Hin are less than unity except SA10 for $\mathrm{H}_{\text {in }}$. However, the value of gamma index $\mathrm{I} \gamma$ is found to vary from 0.71 to 2.6 with an average value of 1.52 and most values of $\mathrm{I} \gamma$ were also found higher than one. All the values of Alpha index I $\alpha$ were found below the maximum permissible value i.e. For samples SA1, SA6, SA8 and SA10 the ratio of activity concentration $\left({ }^{226} \mathrm{Ra} /{ }^{232} \mathrm{Th}\right)$ is less than unity; this is due to that monazite contains more thorium than uranium. The obtained result in this work can be used as the regional base line data for estimation the future radioactivity contamination in the studied regions. Other studies in Libya disagree with this work due inaccuracy technique or limited regions of study [5] [6].

Therefore, the soil of some regions used in the present study is exempted from all the restrictions concerning radioactivity, also these soil samples are safe to be used in building construction. However, the soil samples of regions as mentioned above have higher values for ${ }^{232} \mathrm{Th},{ }^{226} \mathrm{Ra},{ }^{235} \mathrm{U}$ and radionuclides indices than world (UNSCEAR, 2000) [25]. The mean value of gamma index is obtained above the limit of 1 for most samples. On the basis of these results, researcher concluded that the soil of the study area (in particular regions) had radiological health hazard to the public.

\section{Acknowledgements}

I would like to thank all those people working as a team of experimental nuclear physics department NRC EAEA, who have given help and support in various ways and have made this work possible. 


\section{Conflicts of Interest}

The authors declare no conflicts of interest regarding the publication of this paper.

\section{References}

[1] Ahmed, N.K. (2005) Measurement of Natural Radioactivity in Building Materials in Qena City, Upper Egypt. Journal of Environmental Radioactivity, 83, 91-99. https://doi.org/10.1016/j.jenvrad.2005.03.002

[2] UNSCEAR (United Nations Scientific Committee on the Effects of Atomic Radiation) (1993) Exposure from Natural Sources of Radiation of Radiation. Report to the General Assembly, United Nations.

[3] Eyebiokin, M.R., Arogunjo, A.M., Oboh, G., Balogun, F.A. and Rabiu, A.B. (2005) Activity Concentrations and Absorbed Dose Equivalent of Commonly Consumed Vegetables in Ondo State, Nigeria. Nigerian Journal of Physics, 17, 187-192. https://doi.org/10.4314/njphy.v17i3.38041

[4] El Kameesy, S.U., Abd Elghany, S., et al. (2008) Natural Radioactivity of Beach sand Samples in the Tripoli Region North west Libya. Turkish Journal of Engineering and Environmental Sciences, 32, 245-251.

[5] Najim Askouri, A., Husain, M.O., et al. (2011) Natural Radioactivity Survey in Al-Jabal Al-Gharbi Mountain Region Libya. Iraqi Journal of Physics, 9, 96-101.

[6] Abu Haija, O. (2012) Determination of Natural Radionuclides Concentrations in Surface Soil in Tafila/Jordan. Modern Applied Science, 6, 87-90.

https://doi.org/10.5539/mas.v6n3p87

[7] Ibrahiem, N.M., Abd El Ghani, A.H., Shawky, S.M., Ashraf, E.M. and Farouk, M.A. (1993) Measurement of Radioactivity Levels in Soil in the Nile Delta and Middle Egypt. Health Physics, 64, 620-627. https://doi.org/10.1097/00004032-199306000-00007

[8] UNSCEAR (2000) Effects of Atomic Radiation to the General Assembly, in United Nations Scientific Committee on the Effect of Atomic Radiation. United Nations, New York.

[9] Majolagbe, S.B., Faromika, O.P., et al. (2014) Determination of Natural Radioactivity in Soil Samples of Some locations in Akure, Ondo State/Nigeria. International Journal Scientific Engineering Research, 5, 1454-1459.

[10] Beretka, J. and Mathew, P.J. (1985) Natural Radioactivity of Australian Building Materials, Industrial Wastes and Byproducts. Health Physics, 48, 87-95. https://doi.org/10.1097/00004032-198501000-00007

[11] Schimmack, U. and Diener, E. (1997) Affect Intensity: Separating Intensity and Frequency in Repeatedly Measured Affect. Journal of Personality and Social Psychology, 73, 1313-1329. https://doi.org/10.1037/0022-3514.73.6.1313

[12] Turham, S., Bayank, U.N. and Sen, K. (2008) Measurement of the Natural Radioactivity in Building Materials Used in Ankara and Assessment of External Doses. Journal of Radiological Protection, 28, 83-91. https://doi.org/10.1088/0952-4746/28/1/005

[13] Krieger, R. (1981) Radioactivity of Construction Materials. Betonwerk FertigteilTechnik, 47, 468-473.

[14] Ahmed, S.M.F., Sroor, A., El-Bahi and Abdel-Hakeem, A.S. (2001) Natural Radioactivity and Radon Exhalation Rate of Soil in Southern Egypt. Applied Radiation 
and Isotopes, 55, 873-879. https://doi.org/10.1016/S0969-8043(01)00123-3

[15] Genie (2000) Spectroscopy System Operations. Canberra Industries, Meriden. http://www.Canberra.com

[16] Lamoure, I.A., Wagiran, H., et al. (2012) Natural Radioactivity Measurements in the Granite Rock of Quarry Sites. Johor, Malaysia. Radiation Physics and Chemistry, 81, 1842-1847. https://doi.org/10.1016/j.radphyschem.2012.08.005

[17] Cetin, E., Altinsoy, N. and Orgün, Y. (2011) Natural Radioactivity Levels of Granites Used in Turkey. Radiation Protection Dosimetry, 151, 299-305.

[18] Aközcan, S. (2014) Natural and Artificial Radioactivity Levels and Hazards of Soils in the Kücük Menderes Basin, Turkey. Environmental Earth Sciences, 71, 4611-4614. https://doi.org/10.1007/s12665-013-2861-6

[19] Sroor, A., El-Bahia, S.M., Ahmed, F. and Abdel-Hakeem, A.S. (2001) Natural Radioactivity and Radon Exhalation Rate of Soil in Southern Egypt. Applied Radiation and Isotopes, 55, 873-879. https://doi.org/10.1016/S0969-8043(01)00123-3

[20] Omar, S.Y. (1997) Determination of the Concentration of Natural and Man-Made Radioactivity in the Northeast Region of Libya. PhD Thesis, Faculty of Science Cairo University, Giza.

[21] UNSCEAR (2000) Sources and Effects of Ionizing Radiation. UN, New York.

[22] Sahin, L. and Cavas, M. (2008) Natural Radioactivity Measurements in Soil Samples of Central Kutahya (Turkey). Radiation Protection Dosimetry, 131, 526-530. https://doi.org/10.1093/rpd/ncn243

[23] Kinyua, R., Atambo, V., et al. (2011) Activity Concentrations of ${ }^{40} \mathrm{~K},{ }^{232} \mathrm{Th},{ }^{226} \mathrm{Ra}$ and Radiation Exposure Levels in the Tabaka Soapstone Quarries of the Kisii Region, Kenya. African Journal of Environmental Science and Technology, 5, 682-688.

[24] Jibiril, N.N., Farai, I.P. and Alausa, S.K. (2007) Estimation of Annual Effective Dose due to Natural Radioactive Elements in Ingestion of Foodstuffs in Tin Mining Area of Plateau, Nigeria. Journal of Environmental Radioactivity, 94, 31-40. https://doi.org/10.1016/j.jenvrad.2006.12.011

[25] Ajay, K., Kumar, A. and Singh, S. (2012) Analysis of Radium and Radon in the Environmental Samples and Some Physicochemical Properties of Drinking Water Samples Belonging to Some Areas of Rajasthan and Delhi, India. Advances in Applied Science Research, 3, 2900-2905. 